\title{
RUSSIAN-ESTONIAN RELATIONS AFTER 2007: CUR- RENT STATUS AND DEVELOPMENT PROSPECTS
}

\author{
Agata Włodarska
}

\begin{abstract}
The article highlights the major points that have influenced relations between Russia and Estonia after 2007. These relations were rather poor during the post-Soviet period. The number of Russian people who lived in Estonia after gaining independence in 1991 exceeded 30\%, which resulted in the very keen interest of Russia in Estonian politics. April 2007 created a new reality for relations between the countries. The decision to move the statues of Second World War Soviet soldiers from main squares to cemeteries provoked negative reactions from Russians living in Estonia, but also infuriated leaders of the Russian government. As a consequence there were harsh verbal attacks from Moscow, the Estonian ambassador to Moscow was harassed, cyberspace attacks took place and traffic over the bridge in Narva, which is a key highway from Russia, was blocked. The Estonian authorities know there is no point in maintaining conflict with Russia. The President of Estonia, Toomas Hendrik Ilves, has stressed that Estonia's relationship with its biggest neighbour, Russia, can only get better. Russia plays an incredibly important role in the Estonian economy and tourist industry, according to Andrus Ansip, the Prime Minister of Estonia.
\end{abstract}

KEY WORDS: Russian - Estonian relations, Bronze Soldier Night, cyber attacks in Estonia, The Estonian State Integration Programme, Russians in Estonia

- stonia is a country, which is strongly divided taking into consideration the isUsue of ethnicity. Nevertheless, from 1991 Estonia has made rapid progress in establishing both a democratic political system and a free-market economy. In the first years after gaining independence it was very important to follow a political course which strengthened the democratic system and to integrate Estonia with 
the EU structures and NATO. Joining the EU and NATO were the key goals of foreign policy. Relations with Russia were also significant and crucial for many reasons ${ }^{1}$.

It should be noted that relations between Estonia and Russia have been rather poor during the post-Soviet period. There were some breakthroughs and brighter moments but those occasional events were not significant enough to melt the icy silence and develop cooperation between these two countries. The restructuring of the historically difficult relations was anticipated to take place after the enlargement of the EU and the accession of Estonia to this organization. Unfortunately, three years after Estonia joined the EU, the permafrost in Estonian-Russian relations shows no sign of melting. Moreover, the poor relations have become worse. The issue of the Russian minority living in Estonia remains on the agenda. It has turned out that leaving the past behind and starting new and consensual activities is impossible at this time ${ }^{2}$.

The inquiry regarding the poor and weak relations between Estonia and Russia seems to be as topical as ever before. Estonian relations with Russia remain difficult and tough because Russian authorities claim that Estonia does not respect, and even violates the human rights of Russians living in its territory ${ }^{3}$.

The problem is with the integration of Russians into Estonian society. The large number of Russians is poorly integrated into Estonia and with Estonians. They are denied Estonian citizenship because they have not completed the procedures of naturalization yet. It should be noted that the Estonian government tries to deal with this issue and initiates new integration programmes. The current program is named The State Integration Programme for 2008-2013. It consists of two parts: a strategy and an action plan, and it aims to achieve its goals by the end of 2013. The main goal of the program is to improve knowledge of Estonian language on all levels, and to increase the contact and communication between groups of people who speak different mother tongues. It is also highly important to build trust among residents from different national groups and for Estonia as a state. The other issue is to get regular information from Estonian-language media to residents who do not speak or understand this language. Moreover the government wants to decrease the differences between the salaries of employees of different nationalities ${ }^{4}$.

The point of the new strategy is to bring Russian residents into the social life of the country. It is strongly linked to enhancing Estonia's inhabitants' involvement in the social sphere. Mutual tolerance and equal chanc-

\footnotetext{
1 S. Woehrel, CRS Report for Congress: Estonia - current issues and U.S. policy, July 2007, p. 1-2, from the Congressional Report Service website [http://www.fas.org/sgp/crs/row/] 02.10.2010.

2 Identity and foreign policy: Baltic-Russian relations and European integration, eds. E. Berg, P. Ehin, Ashgate Publishing Limited 2009 England, p. 1-2.

3 The Russian-speaking minority constitutes approximately $30 \%$ of the Estonian population. $24.9 \%$ of the Estonian population are Russians (as of 01.01.2008). At the beginning of 2000 it was 25.6\%, at the very end of the 1990s the number of Russians in Estonia was higher, it was 30.3\%. (The data are taken from the website Estonia.eu - official getaway to Estonia -02.10.2010: http://estonia.eu/about-estonia/country/ population-by-nationality.html).

4 Estonia.eu - official getaway to Estonia: http://estonia.eu/about-estonia/society/integration-inestonian-society.html (02.10.2010).
} 
es, irrespective of nationality, are the basic requirements of every society ${ }^{5}$. After 1991, knowledge of the Estonian language was essential to get citizenship of this country. The number of people who did not get Estonian citizenship after independence in 1991 was rather high. People whose ancestors were not citizens of Estonia before the accession to the Soviet Union in June 1940 had to apply for citizenship and had to fulfil certain requirements, such as knowledge of Estonian language and history. Without citizenship those people could not vote in national elections and did not have the rights which were guaranteed to all citizens. Furthermore, Russians living in Estonia suffered from higher unemployment than ethnic Estonians, and their standard of living was much lower. This was mainly due to their jobs. Russians were paid less than ethnic Estonians ${ }^{6}$. These issues have influenced Russian - Estonian relations after $2004^{7}$.

After joining the EU and NATO, Estonia faced new challenges. The country was seen as an active and influential participant in the change process. However, there was a danger that Estonia could be marginalized within the EU and bilateral conflict with Russia fostered. From May 2004 all forms of communication between Russia and Estonia had to take place in the context of Estonia's membership of the EU. Estonia's belonging to the EU system influenced both political and non-political relations with Russia.

Estonia put bilateral problems on the agenda of the institutions in Brussels. Another key issue for Estonian political leaders was Russia's responsibility for creating the USSR's Estonian policy. The most significant consequence of this policy was that a huge number of Russians moved to Estonian territories during the Soviet period ${ }^{8}$.

April 2007 was a very significant time for relations between Estonia and Russia. The crisis appeared because of the Estonian decision to move the statue of a Second World War era soldier ${ }^{9}$ from the main park in the capital of Estonia - Tallinn ${ }^{10}$. The change of the

5 T. Mătlik, Estonian Integration Strategy 2008-2013, Tallinn Conference on Conceptualizing Integration, 18-19. 10.2009 (http://www.migpolgroup.com/public/docs/149.TallinnConferenceReport_18-19.10.07.pdf; 07.10.2010).

6 The income of Estonian - Russians is strongly determined by their citizenship. Estonian - Russians with Russian citizenship and Russian speaking people with undetermined citizenship (before 1991 they were the citizens of Soviet Union) earn significantly less than Estonian - Russians with Estonian citizenship and Estonians. It must be underlined that Russians with Estonian citizenship are younger and better educated, what is more their level of language proficiency is also more advanced. It is easier for them to find a better job and be satisfied with it.

$7 \quad$ A. Włodarska, The structure of unemployment in Estonia after 1991, [in:] "XXI wek: Gumanitarnye i Socialno - Ekonomiceskie Nauki", Tuła 2010, p. 122-125.

8 V. Made, Estonian - Russian relations in the context of the international system, p. 102-105. This study was commissioned by the Foreign Affairs Committee of the European Parliament in August 2004. It was published in October 2004 (date taken from the website on 02.10.2010: http://scholar.google.pl/ scholar?q=the+estonian+-+russian+relation+in+the+context+of+the+international+system \&hl=pl\&as _ sdt=0\&as_vis=1\&oi=scholart).

9 Enn Roos was the creator of the Bronze Soldier statue in 1947. The supervising architect was Arnold Allas. The monument was unveiled on the third anniversary of Red Army soldiers entering Tallinn in 1944 (22nd September 1947). Later, in 1964, the eternal flame was added in front of the statue.

10 The Protection of War Graves Act was passed by the Estonian Parliament - Riigikogu - on 10th January 2007. The document established the legal foundation for the relocation of the statue from the centre of Tallinn to the military cemetery. 
monument's location provoked negative reactions from Russians living in Estonia, but also infuriated leaders of the Russian government. According to the Russians, this action dishonoured the Red Army soldiers who liberated Estonians and defeated Nazi Germany ${ }^{11}$.

The decision to relocate the Bronze Soldier statue was not made lightly. The Russians accused Estonians of rewriting history and ignoring those whose relatives died in the Second World War. Pro-Soviet nostalgia was fully approved by the Russians and they could not understand why a statue was such a problematic thing for Estonians. The most significant shortcoming of the Estonian government in the relocation process was that it failed to treat the relocation as an important event, but rather as a bureaucratic, technical and legally correct transfer. Russians claimed that nobody was interested whether there was anyone who was troubled by this relocation.

The night of 27th April 2007 is referred to by both Estonians and Russians as bronze night or bronze soldier night. During that night, groups of young Estonian Russians gathered in the centre of Tallinn to demonstrate against the relocation of the statue. The situation became pretty dangerous. The Russians did not want the monument to be relocated from the main square so they threw stones at the police, they misbehaved and shouted. Pieces of broken glass were almost everywhere. This situation posed a real danger to human life. One Russian lost his life on this night ${ }^{12}$.

In addition, the monument transfer had further consequences. Firstly, there were harsh verbal attacks from Moscow, secondly the Estonian ambassador to Moscow was harassed by a group of young people closely tied to the Kremlin. In the capital of Estonia more violent demonstrations were organized by active groups of ethnic Russians. The Internet infrastructure in Estonia was also attacked by hackers ${ }^{13}$.

The cyberspace attacks were extremely troublesome for the Estonian authorities and society. The director of Estonia's Computer Emergency Response Team, Hillar Aarelaid, claimed that Estonian leaders could predict some patterns of behaviour because they knew them from experience. He underlined that if there are fights on the streets, there are going to be fights on the Internet. The internet is a regular tool used by Estonians. It is a method of voting, paying taxes, shopping, making phone calls. The cyber war lasted three weeks and forced Estonian leaders to defend their country. The monument relocation precipitated a data flood which was considered to be initiated by the Russians ${ }^{14}$.

The Russian government strongly denied any participation in these cyber space actions. Estonia involved experts from the EU and NATO, the USA and Israel, who tried to help solve the Internet problems ${ }^{15}$. Hackers broke into the websites of many key institu-

\footnotetext{
11 S. Woehrel, CRS Report for Congress..., p. 3-4.

12 I. Melchior, Beyond the cold bronze, [in] Cultural Anthropology Bsc. \& Sociology Bsc., 2007, p. 1, (http://www.google.pl/\#hl=pl\&biw=1001\&bih=638\&q=beyond+cold+soldiermelchior\&aq=f\&aqi $\left.=\& a q l=\& o q=\& g s \_r f a i=\& f p=e 6 a a 7 e 8098997018-09.08 .2008\right)$.

13 The attacks were prepared in late April and early May. According to the Estonians, the cyber attacks were from web services of the Russian government. The Estonian government asked the Russian authorities for help in investigating the cyber attacks, but the Russians refused cooperation in this case.

14 J. Carr, L. Shepherd, Inside Cyber Warfare: Mapping the Cyber Underworld, 2010, p. 180 - 181.

15 The first digital intruders slipped into Estonian cyber space on 26th April at 10.00 p.m. It was the
} 
tions in Estonia. They posted a fake letter from the Prime Minister Andrus Ansip apologizing for the relocation of such a symbolic monument. Estonian Internet service experts tracked down and blocked all unknown and suspicious addresses. Russia refused any state involvement in helping to catch people who were suspected of cooperation in the cyber space attacks. It should be noted that Dimitri Peskov, the spokesman for the Kremlin underlined that The Estonian side has to be extremely careful when making accusations ${ }^{16}$.

Furthermore, Russia blocked traffic over the bridge in Narva, which is a key highway from Russia. Officially these actions were taken because of renovation. Moscow wanted to punish Tallinn for anti-Russian behaviour and make it change its decision ${ }^{17}$.

Russia tried to make the life of Estonians more difficult. One of several highly spectacular actions was the stopping of a British tourist who strayed over the Russian-Estonian border during a sightseeing tour. The man wandered onto the empty reservoir which lies on the River Narva, marking the border between the two countries. The Estonian side explained that the tourist got lost. The tourist was pretty confused when he saw Russian guards and he discovered that he had crossed the border. The Estonians wanted to convince their neighbours that crossing the border and straying into Russian territory was not deliberate, but a mistake. When the tourist understood that he had entered Russian territory it was too late to turn back. There are two checkpoints between Russia and Estonia in this area and both of them are located rather close to Narva. People who do not keep to the rules have to pay a fine, but the legal regulations on the Russian side are tougher than on the Estonian side. According to Russian law, violating a border crossing can lead up to six months in prison ${ }^{18}$.

Bronze Soldier Night opened a new chapter in Estonian - Russian relations. It was a very important factor in shaping the future relations between the two countries. After gaining the independence Estonians have claimed that only by learning Estonian language Russians can better understand Estonian history, their worries in relation to Russia. Russians living in Estonia know that the Kremlin has its propaganda. They are not blind and they understand the situation around them. Even if they are confused about the current situation of Estonia, the Russian minority in Estonia should know about Estonia's current relations with its biggest neighbour. It is essential for both Russians and Estonians because Russians in Estonia are also citizens ${ }^{19}$.

According to Konstantin Kosachev, the Chairman of the Russian Duma International Relations Committee, Russia would neither understand, nor accept, nor forgive the decision of relocating the monument of The Bronze Soldier. Spring 2007 brought arguably the worst crisis in Estonian - Russian relations since 1991, but

starting point of the first cyber space war.

16 M. Landler, J. Markoff, In Estonia: What may be the first war in cyberspace?, "International Herald Tribune", 28th May 2007, (04.10.2010).

17 S. Woehrel, CRS Report for Congress..., p. 4-5.

18 British tourist held in Russia after straying over the border from Estonia during a sightseeing trip, The Baltic Course 29.09.2010, (http://www.baltic-course.com/eng/tourism/?doc=5585; 06.10.2010).

19 K. Liik, The Bronze Year of Estonian - Russian relations, p. 73-75. http://web-static.vm.ee/static/ failid/053/Kadri_Liik.pdf (03.10.2010). 
after such a significant crisis relations between both countries have improved ${ }^{20}$. It should be noticed that cooperation between Estonia and Russia after the crisis in 2007 has altogether ceased. There are many reasons, from the geographic, political and economic point of view, why these relations should be fostered.

After the riots in the centre of Tallinn, the President of Estonia - Toomas Hendrik Ilves made a statement concerning the events in the capital. Ilves did not talk about Russians, he concentrated on the situation which took place in Tallinn ${ }^{21}$. Later it was made clear that Estonia's aim was not to be in conflict with Russia. Both cooperation and good relations are key issues for Estonian leaders and Estonians. The president of Estonia claims that Estonian's relationship with its biggest neighbour, Russia can get only better ${ }^{22}$.

To facilitate quicker border clearance for lorries crossing the Russian-Estonian border the Estonian government introduced a new regulation to customs law. Estonia wanted to accelerate the transport of certain goods, like animals, birds, fast spoiling food, magazines, newspapers and materials used in medicine.

In September 2010 Siim Kiisler, Estonian minister of regional affairs, pointed out that the Estonian-Russian border is not a wall but a window for Estonia. His counterpart from Russia, Viktor Basargin, agreed that border cooperation between both countries is essential for further development and it opens new possibilities. The ministers met in St Petersburg to discuss the cross-border programme which will be financed by the EU with nearly 13 million euro. Money from both the Estonian and Russian governments will also be added to this project. The project will bring new investments and create new places of work for both Estonians and Russians. For Estonian leaders it is important to support and develop water tourism on Peipsi Lake, to improve the infrastructure at the Narva - Ivanogorod border crossing and to develop tourist border-crossing infrastructure in south-east Estonia. Agreements in the sphere of cross-border cooperation were also discussed during this meeting. The border cooperation programme involving Estonia and Russia ${ }^{23}$ was introduced in 2004-2006 ${ }^{24}$. The final project was announced for the years 2007-2013 and was included into the framework of the European Neighbourhood and Partnership Instrument.

Estonian leaders have been arranging many state actions that should enhance rela-

$20 \quad$ Identity and foreign policy..., p. 86.

21 What we witnessed in Tallinn last night was looting, uproar, plundering. It was a crime, and those who took part in it are criminals (...) I hope for the support and understanding of all parents and teachers, for their readiness to explain, both at home and at school, that participation in brutal violations of public order will leave a stain on the whole future of young people. (The data are taken from the website: President of the Republic of Estonia 04.10.2010: http://www.president.ee/en/speeches/statements.php?arhiiv=2010).

22 Russia: Estonian President says Moscow sees Democracy as threat: June 5, 2007. Estonian President Toomas Hendrik Ilves spoke with correspondents Jeffrey Donovan and Irena Chalupa about his country's vulnerability after weeks of cyber attacks and Estonia's relations with Russia. (The data are taken from the website: Radio Free Europe, Radio Liberty 04.10.2010: http://www.rferl.org/content/article/1076942. html).

23 Latvia is also involved into the Cross Order Cooperation Programme.

24 On 6th July 2006 in Riga there was an international meeting of Russian, Estonian and Latvian counterparts who established the Joint Task Force (JTF), the preparation programme. JTF consisted of representatives of all three countries. There were both representatives of national institutions and local authorities. It was organized on partnership principles. 
tionships amongst a society consisting of different national groups. To increase citizens' awareness about the adoption of the euro currency in Estonia they organized a bilingual information campaign. The main aim of the campaign was to provide details of the transition to the euro zone ${ }^{25}$. Jürgem Ligi, Minister of Finance, announced that it was highly important to distribute all information in two languages. He also stated that Estonia is the first country where a euro awareness programme was carried out in more than one language. Estonia's experience is believed to be a model for other Baltic states - Lithuania and Latvia ${ }^{26}$.

Recent events indicate that Estonia tries to cooperate with Russia and build a good atmosphere for further actions. One of the most significant gestures was the dispatch of professional fire-fighting equipment to Russia, suffering from huge fires in the summer of 2010. In addition, the Estonian government decided to allocate 100,000 Euros $^{27}$ to Russia as financial assistance to help the victims of this natural disaster. Urmas Paet, Minister of Foreign Affairs, underlined that the Estonian authorities wanted to help Russians who had been gravely affected by the fires. Other action was taken by the Ministry of Foreign Affairs and Ministry of International Affairs. To help all Russians citizens who were unable to return to their homes, the citizenship department office and the migration department office facilitated procedures extending their visas ${ }^{28}$.

A new study concludes that the integration of the Russian minority in Estonia has been improving ${ }^{29}$. What is more, the relations between different nations living in Estonia are getting closer. This is possible because of the Estonian language. Non-Estonians have improved their language skills, and fluent communication helps them to not be afraid of losing their cultural characteristics. It should be noted that the Estonian language is pretty popular with representatives of the young generation. More than two-thirds of Russianspeakers living in Estonia up to the age of 39 can communicate in the Estonian language. In addition, three-quarters can not only speak, but also read Estonian. However, state institutions are not trusted, according to Russians and Russian-speakers living in Estonia ${ }^{30}$. To sum up, future development prospects for relations are getting better be-

25 The first bilingual information campaign was organized in Narva and the euro exhibition was open to visitors for a month from mid-August until mid-September 2010. It took place at the Astri shopping centre.

26 Estonia organizes bilingual euro-awareness raising groups. The Baltic Course, Tallinn 19.08.2010, http://www.baltic-course.com/eng/finances (07.10.2010).

27 It was more than 1,5 million kroons.

28 The Estonian Government allocated an additional 1.5 million kroons for Russian fire victims, The Baltic course, Tallinn 13.08.2010, The data are taken from the website The Baltic Course 04.10.2010 http:// www.baltic-course.com/eng/finances/.

29 The study was carried out by the International and Social Studies Institute of Tallinn University, with the support of the Culture Ministry and Integration and Migration Foundation Our People. (The data are taken from the website The Baltic Course: Estonia's Russian-speaking population becomes increasingly alienated from the state, Tallinn, 15.09.2010) http://www.baltic-course.com/eng/education/?doc=31621 (04.10.2010).

30 The study shows that 31\% Russian-speakers trust the police, $29 \%$ trust the courts, $9 \%$ trust to government, 7\% trust the Riigikogu and 14\% trust the president. In comparison 60\% Estonian-speakers trust the police, $40 \%$ trust the courts, $32 \%$ trust the government, $18 \%$ trust the Riigikogu, $67 \%$ trust the president. 
cause of cooperation between Estonia and Russia. Andrus Ansip, Estonian Prime Minister, claims that Russia is playing an incredibly important role in the tourist industry and economy in Estonia. The number of tourists who visited Estonia from 2007 to 2009 was higher than in the previous years ${ }^{31}$. Estonian leaders underline that relations with Russia are good and it is believed that this will continue. $(52-54 \%)$. 